\title{
Correction to: The Influence of In-Cavity Pressure on Heat Transfer and Porosity Formation During High-Pressure Die Casting of A380 Alloy
}

\author{
M.S. DARGUSCH $\circledast{ }^{1,4}$ A. HAMASAIID, ${ }^{1,2,3}$ G. DOUR, ${ }^{2}$ \\ N. BALASUBRAMANI, ${ }^{1}$ and D.H. STJOHN ${ }^{1}$ \\ 1.-School of Mechanical and Mining Engineering, The University of \\ Queensland, St. Lucia, Brisbane, QLD 4072, Australia. 2.-IMT Albi-Carmaux, Institut \\ Clément Ader. ICA-Albi, Route de Teillet, 81013 Albi Cedex 09, France. \\ 3.-3DmetDie, 118, 20 Chemin de la Teulière, 81000 Albi, France. 4.-e- \\ mail: m.dargusch@uq.edu.au
}

\section{CORRECTION TO:}

JOM

HTTPS://DOI.ORG/10.1007/S11837-020-04341-Y

This article was updated to correct the spelling of A. Hamasaiid's name.
Publisher's Note Springer Nature remains neutral with regard to jurisdictional claims in published maps and institutional affiliations. 